\title{
AUC Dosing to Last Concentration Normalized by Body Mass Index
}

National Cancer Institute

\section{Source}

National Cancer Institute. AUC Dosing to Last Concentration Normalized by Body MasS

Index. NCl Thesaurus. Code C92309.

The area under the curve (AUC) from the time of dosing to the last measurable concentration divided by the body mass index. 